\title{
Environmental Impact Evaluation of the Industry of Panela by Life Cycle Analysis
}

\author{
Dr. C. Walter Francisco Quezada Moreno ${ }^{1}$., Dra. C. Ana Margarita Contreras Moya ${ }^{2}$, \\ Dra. C. Elena Rosa Domínguez², Dr (asp.). David Quezada Torres², Mg. Franklin \\ Antonio Molina Borja ${ }^{1}, \mathrm{Mg}$. Jaime Orlando Rojas Molina ${ }^{1}$
}

\author{
${ }^{1}$ Department of research, Technical University of Cotopaxi. \\ ${ }^{2}$ Department of Chemical Engineering. University "Marta Abreu" of Las Villas. Carr. a Camajuani Km 51/2. Santa Clara, \\ Villa Clara. Cuba.
}

\begin{abstract}
The objective of the study is to evaluate the environmental impacts generated by the industry of the panela in Ecuador, using the Life Cycle Analysis methodology. The in situ information gathered allowed the identification of the sensitive environmental factors that are affected in all the operations that are carried out in the agroindustry of panela.

The results show that the craft activities prevail rather than the industrial activities, due to the low industrial development, application and control of regulations, rudimentary manufacturing practices, among others; which have led to insufficient productivity, competitiveness, quality and safety of their products. The results of the Environmental Impact Assessment, using the Eco-Indicator 99 method, according to the Life Cycle Analysis technique, show that the industrial stage has the greatest contribution to the impact, being more representative the impact to the effects by respiration of inorganic compounds, acidification / eutrophication, climate change and land use. The impact level of this type of industry according to Ecuador's environmental legislation, places it as an industry that generates moderate environmental impacts, it does not require intensive protective or corrective practices. However, it requires environmental executive actions oriented to the control and prevention to mitigate these impacts.
\end{abstract}

Keywords- Agroindustry of Panela, Life Cycle Analysis, Environmental Impact.

\section{INTRODUCTION}

As societies progress and develop, the energy demands and their environmental effects grow. A balance between production and consumption can be achieved if all the agents acting on the market do so in a responsible way[1], where quality and competitiveness must be fully justified by actions of continuous improvement and innovative efforts for clean and safe productions.

The agroindustry of panela in Ecuador has the purpose of developing productive activities from the cultivation, processing and commercialization of sugar cane for panela, natural sugar and honey. Its effects in terms of employment multiplication, value addition, and nutrients are high [2] [3]. It is estimated that there are 519 agroindustries, production units of panela in the country that use fuel materials for the process such as bagasse, firewood and tires alone or combined [4]. The lack of quality, harmlessness, diversification of production, assessment of productive yield and use of by-products are some of the problems that have generated its lag. In the agroindustry of panela the activities of handcrafted character prevail over the activities of industrial character. However, efforts are being made in technological improvements in the panela production, natural sugar and recent studies with cane honey, for commercial purposes [5]. In spite of the importance of the sector and the existence of environmental legislation, its execution with technical and environmental obligations has not yet materialized, affecting the productivity, quality and harmlessness of its products and environment.

In the industry of panela, the cleaner productions must be a reality and of business fulfillment and awareness. Clean Productions are safe and ultimately economical and necessary for the sustainability of a technological process. Innovative efforts are required from a technical-economic and environmental point of view to achieve improvements and higher productivity with lower resources, which must be valued environmentally to favor their investments and secure the market.

Environmental assessments are valid tools that have become in actions in the business and governmental world to understand and manage the risks and opportunities of the stages of the life cycle of a product or process towards the introduction of scientific knowledge to describe associated environmental impacts.

\section{1 Agroindustry of Panela}

Panela activity is a subsector of the agro industrial sector, where the panela is the main sweetener obtained by extracting, cleaning and concentrating the juice of the 
cane. It is a fundamental pillar for rural social, economic, cultural development and for the sovereignty and food and nutritional security of many countries in Asia, the Caribbean and South America [4] [6]. This activity in most factories is developed neglecting technical, environmental and quality standards throughout the process line.

The activities are more handcrafted than industrial; due to its poor development, application and control of regulations, rudimentary manufacturing practices, among others; which have led to insufficient productivity, competitiveness, quality and harmlessness of their products. However, it plays a key and an important role for food sovereignty and security, allowing safe and permanent access to sufficient and nutritious food in all markets, especially in rural and marginal urban areas.

This activity uses different materials for the production and commercialization: water, energy, cane and vegetal and chemical mucilages in the clarification of juice as clarol or sodium hydrosulfite, carbonates, vegetable fats, fuels and others [7] [8].

Deforestation for firewood and the establishment of cane cultivation, the preparation of the land and the application of agrochemicals for its management, coupled with the low efficiency of combustion and heat transfer processes in the burner, are activities that generate negative changes in environmental quality.

In many cases, the sustainability of the activity to concentrate juice to obtain panela is at risk, due to the lack of environmental awareness. The inefficiency of the panela burners, the use of wood that affects the forests, tires and greenhouse plastics to generate energy and that give off toxic gases such as carbon monoxide $(\mathrm{CO})$ and nitrogen to the atmosphere, are aspects that weaken its activity. $\mathrm{CO}$ is a pollutant; it is the product of the incomplete combustion of any type of fuel. The tires have sulfur in the form of sulfides that in the burning they are oxidized and released into the air as a pollutant. This type of reaction is characterized by the presence of combustible substances or also called unburned in the combustion gases, such as carbon in the form of ash, $\mathrm{CO}$ and $\mathrm{H}_{2}$. Bagasse, firewood and tires generate compounds such as $\mathrm{CO}_{2}, \mathrm{CO}, \mathrm{NOx}, \mathrm{SOx}, \mathrm{H}_{2}, \mathrm{H}_{2} \mathrm{O}$ and other gases and particles, energy and ash. In the stage of clarification, evaporation and concentration the negative effects are evidenced by the generated and untapped water vapor, the use of flocculants and the presence of wastes [9].

In spite of the multiple advantages of cane in the agroindustry of panela in Colombia and Ecuador, it has an undesirable impact due to the consumption of large amounts of fuel wood and used tires and the energy inefficiency of the burners. Up to three tons of firewood per ton of panela are used, generating problems of deforestation, soil erosion and pollution [10] [4], so its environmental effect is highly negative. The calorific power of a tire is $8300 \mathrm{Kcal} / \mathrm{kg}$ and the gases that are derived are compounds of carbon, nitrogen and sulfur. Carbon black creates disorders in the respiratory system. Energy efficiency in the operation of the burner, good manufacturing practices and safety and good use and waste management, is determinant to avoid negative impacts to the environment in the activity of the agroindustry of panela. However, environmental degradation and overexploitation of natural resources can weaken a country's competitive base [11]. For this reason, a concept is needed that manages access to raw materials and imposes controls on improper processing practices in order to maintain the integrity of the environment and protect natural resources, and another that on the other hand, it is required an understanding of the competitive nature of the agroindustrial sector and the entrepreneur's unique role [12]. Planning is required for efficient performance in the technological and economic systems of the activity of the panela that does not adversely affect society and the natural environment. Consumers show and demand a growing interest in knowing what is behind each product, since, apart from the quality and safety of food, the health and welfare of the community and the quality of the environment are ahead.

\subsection{Environmental analysis}

Cities require food, paper, water, and other products every minute, so as by-products of their processes emit large quantities of particulate material, $\mathrm{CO}, \mathrm{SO}_{2}, \mathrm{NOx}$ and other gases as well as large volumes of solid and liquid wastes [13]. Therefore, despite a great effort in research and action aimed at avoiding environmental pollution, it remains a worldwide concern.

Life Cycle Analysis (LCA) is an environmental management technique to evaluate the potential environmental aspects and impacts associated with a product [14] [15]. It is a tool to examine the environment of the serious consequences of the manufacture and use of products or the provision of services [16]. It allows the systematic evaluation of the environment and aspects of a product or service system through all stages of its life cycle [17] [18]. The LCA is positioned as a key tool for the evaluation of potential environmental impacts, as well as for the generation of useful scientific and technical information for the orientation of environmental policy and legislation; the establishment and strengthening of integrated waste management programs and management plans among other policy instruments, as well as the decision-making in the industrial and social sectors [19].

The LCA means recognizing how our choices influence each stage of the process and thus weighing the advantages and disadvantages contributing to the 
economy, the environment and society [20]. It is essential for the sustainable development, to go beyond traditional production to one with responsibility, where economic, environmental and social aspects prevail [21]. The application of the LCA technique in the industry of panela constitutes a viable and applicable tool for the entire chain of production, considering internal and external effects.

The greatest contribution is to think and act to mitigate adverse effects to the environment, caused by industrial processes, market or consumption. It is not only generating work, development or food, is to produce thinking about the welfare of all. It is health and good living. It is economic growth, ecological balance and social progress [22]. The global implementation plan for Sustainable Development calls for: "improving products and services while reducing health and environmental impacts, using scientific models such as life-cycle analysis where appropriate" [23].

The execution of LCA studies to the sector, analyzing the productions of the activity of panela including the natural sugar, honey and byproducts that it generates, will allow a comprehensive diagnosis of the environmental situation of this activity in the countries of the world and in Ecuador especially.

\subsection{Environmental Legislation}

Due to its level of pollution, industry in general has worldwide been permanently under the eyes of the community. FAO General - Director José Graziano said in Santiago de Chile that climate change is not a problem of the future but the present. He has warned of its impact in South America, he said that the impacts are being greater than what was thought and yet it is not known how it will affect food production [24].

Concern about the environmental deterioration due to industrialization at a global level has determined that the sustainability of the sector in the country is determined to comply with the current environmental legislation in the sector and country. However, its application and control has not had results, its breach is visible and notorious. According to Annex I of the National Environmental Categorization Catalog (CCAN), for the construction and / or operation of factories for the production of panela, it is classified in group II, considered of low impact and requires an environmental file [25].

The government of Ecuador has implemented demanding environmental legislation with respect to the environment, but, these provisions are not fulfilled in the sector. In Ecuador, Local and Provincial Governments known as GAD have legislations that try to regulate certain activities, but with unsatisfactory results for the community. The existing normative instruments of environmental legislation under the present Constitution of the Ecuador Republic grouped in the Unified Text of Environmental Legislation TULAs and the Organic Law of Municipal Regime guides the way of control of productive activities [26]. Considering the impact that the whole production chain has on the environment in a holistic manner will be decisive for the sustainability process of the sector [27].

\section{MATERIALS AND METHODS}

A bibliographical review about the industry of panela was carried out and data were collected through an in situ diagnosis to the agroindustries of panela in the center and north of the country. It is estimated that there are 519 productive units. In three production units, the gas produced by combustion was measured using the Einstrument 4400 equipment. The first unit of panela operates with bagasse, the second with firewood and the third uses pneumatic tires. In addition, the control in the diesel engine was carried out to operate the equipment of cane juice extraction.

For the environmental evaluation, applying the methodology of Life Cycle Analysis was considered as a case study the unit of panela that operates with bagasse only. It has a processing capacity of $20 \mathrm{t}$ cane / day, where noise was also evaluated using the EXTECH Instruments sound level meter, ranging from 26 to $130 \mathrm{~dB}$ (A). Controls of wastewater volume, $\mathrm{pH}$ and soluble solids (brix) were performed on the liquid wastes from the cleaning, clarifying, concentrating and washing tubs of molds and materials. The environmental effects were analyzed according to the limits of the system shown in figure 1 . 


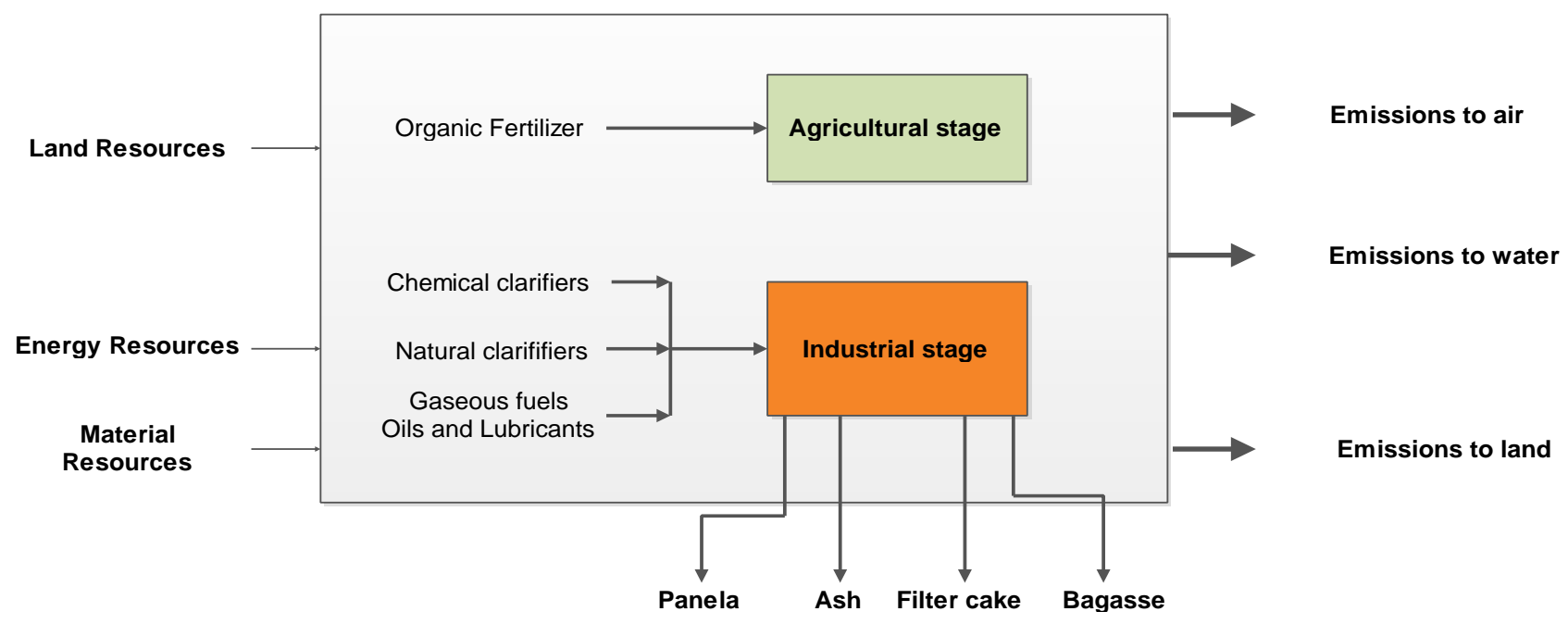

Fig. 1: System limits for LCA in the production of panela.

The general inventory of the unit of production was carried out according to information of the entire productive chain of the activity of panela (cane production, processing and marketing).

The results are plotted and the environmental assessment is performed using the Life Cycle Analysis (LCA) methodology according to the Sima Pro7.3 software and the Eco-indicator 99 methodology, according to the system limits shown and taking as a functional unit the daily production of panela, which corresponds to $2485 \mathrm{~kg}$.

\section{RESULTS}

The balance of material and energy applied through stoichiometric calculations according to the inputs and outputs of products generated the results indicated in figure 2 .

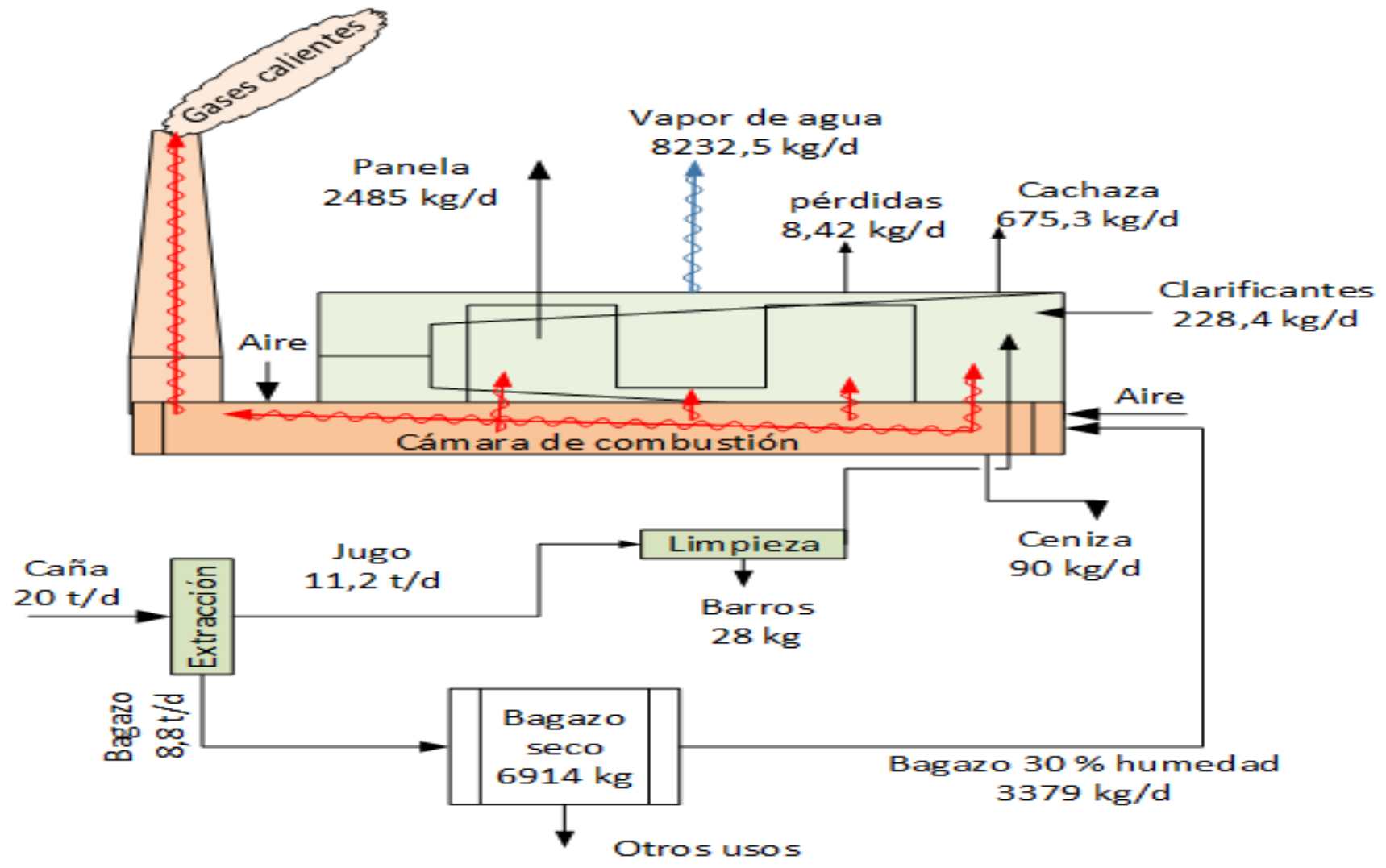

Fig.2: Mass balance and contaminant identification 
The balance of mass and contaminants generated by the 20 tons of cane per day produces $2485 \mathrm{~kg}$ of panela, byproducts and wastes, such as: $8800 \mathrm{~kg}$ of bagasse for combustion (energy needed to concentrate juice to panela) and 1530 liters of wastewaters produced in the different containers which are discharged to the ground and that have natural watercourses as destination. The $\mathrm{pH}$ of the wastewaters and the solids soluble in the solution in the different containers reach values between $4.64-5.11$ and 2.10 to 11.3 brix degrees, respectively.

The analysis of the permissible limits of noise levels for fixed sources, mobile sources and vibrations is done according to the Unified Text of Environmental Legislation (TULAs), which establishes that the sound pressure limit within an industrial zone, is $75 \mathrm{~dB}(\mathrm{~A})$ in an eight-hour noise exposure per day [26]. The results of noise indicate that the point $\mathrm{A}=83.42 \mathrm{~dB}(\mathrm{~A})$, very close to the engine (machine that drives the mill or cane juice extraction equipment), exceeds the permissible limit of noise emissions.

In Figure 3, the average results of 14 measurements performed every 30 minutes on the two burner combustion processes are shown: the first one using bagasse only, the second one operating with wood or firewood (sawmill waste and boxes used to transport fruit) and in the engine. In the burner using bagasse, high temperature values are obtained in the flue gases and the combustion is better, since fewer gases (CO and NO) are obtained in front of the burner that uses wood in the combustion.

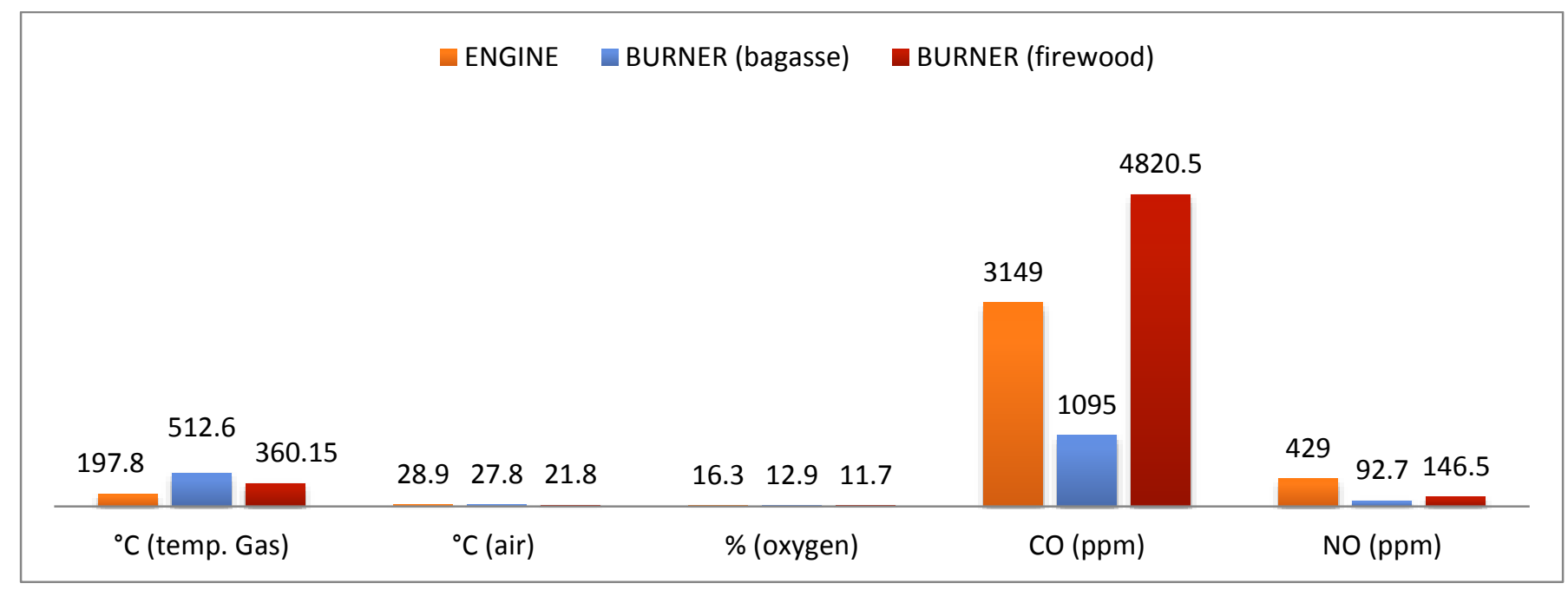

Fig.3: Parameters of the combustion of bagasse, firewood and in the engine.

The generation of gases is within the limit allowed in both, carbon monoxide (CO) and nitrogen (NO); being greater the amounts generated in the wood burner than in the one that uses bagasse. The emission of combustion gases, $\mathrm{CO}$ and $\mathrm{NO}$, in the engine shows high values and is due to the years of work of the equipment (superior to 15 years), very common in most productive units of panela of Ecuador. When assessing measurements on a burner using bagasse and tires, in all measurements the $\mathrm{CO}$ values exceed the measurements reached in the burner using bagasse and firewood, which values are higher than the Environmental Standard of Colombia and Ecuador [26] [27].
Figure 4 shows the results of the life cycle assessment in the production of panela using bagasse in the burner (case study), by means of Sima Pro7.3 software and the methodology of Eco-indicator 99, from the data of the inventory. The network of the process shows that the industrial stage is the one that contributes most to the contamination. Figure 5 shows that the greatest contribution in all impact categories is in the industrial process, with a more representative impact to the respiratory effects of inorganic compounds, acidification / eutrophication, climate change and land use. 


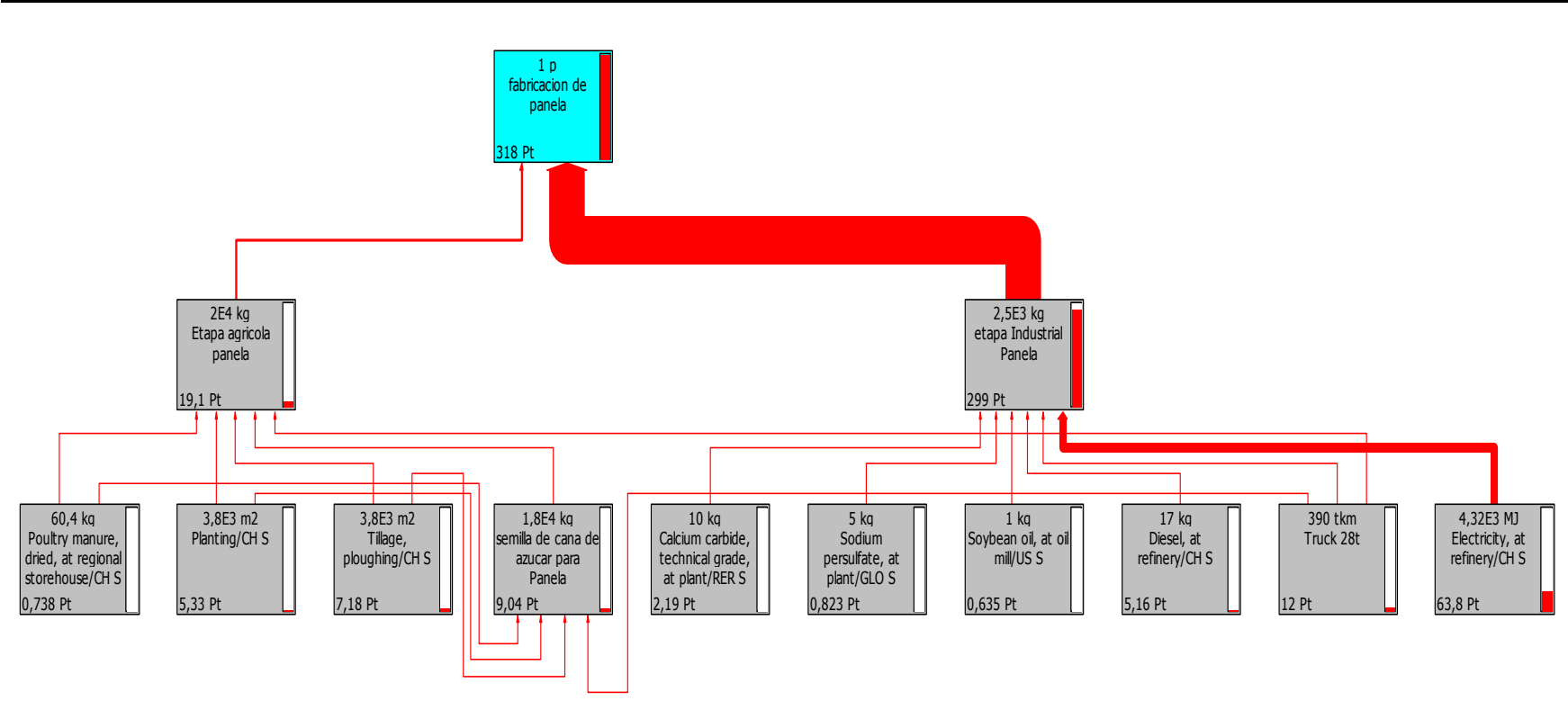

Fig.4: Tree of impacts obtained for the production of panela

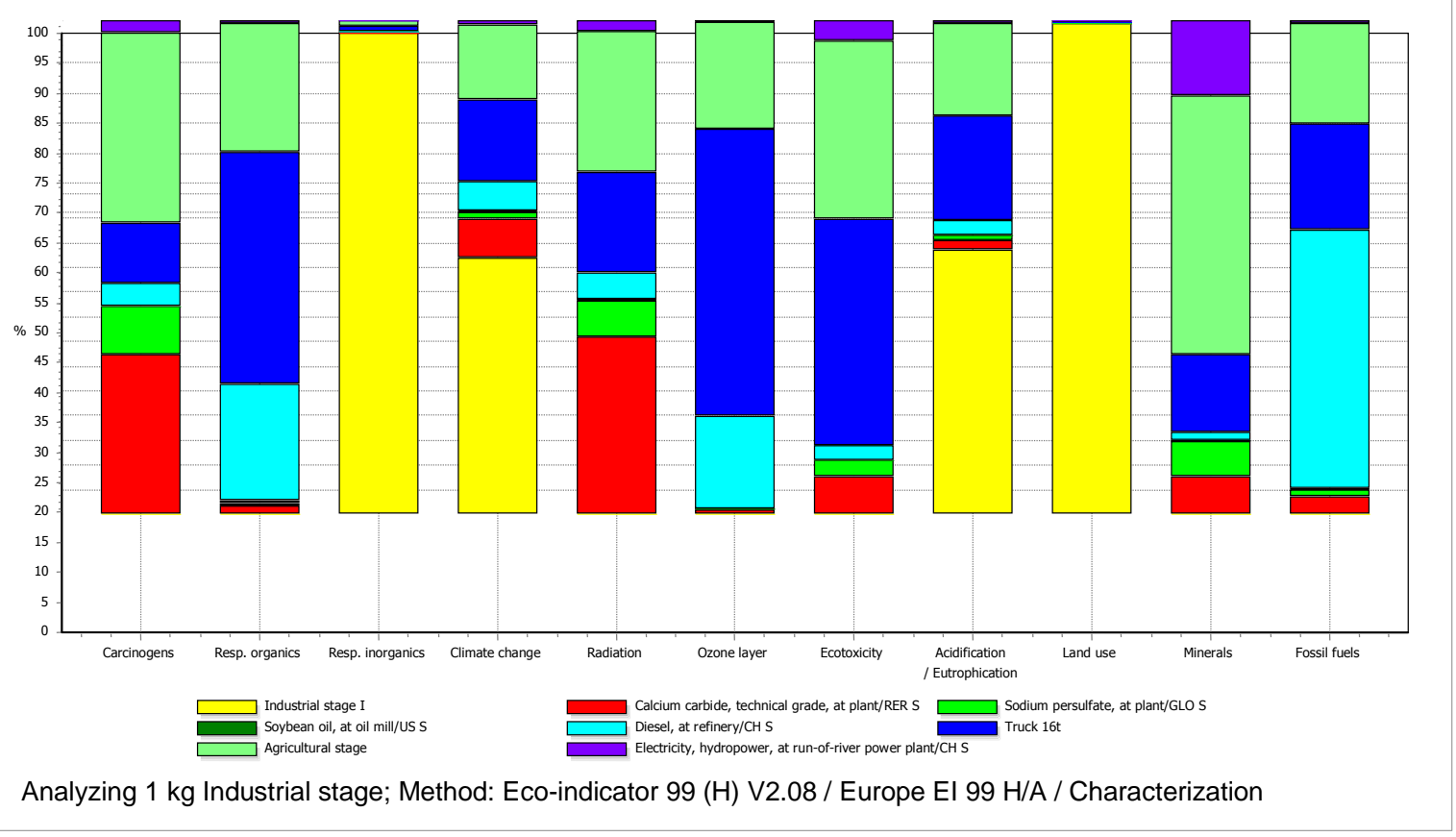

Fig.5: Contribution results by impact category.

From the analysis of the contribution to the categories of damage that is offered in the graph 6 , it is seen that the process has a greater incidence in the damages to the ecosystem, mainly due to the categories of land use and acidification / eutrophication. The effects on human health are related to respiration of inorganic compounds and climate change, and the effects on resources are concentrated on the use of fuel for transportation and electricity in the industrial stage. The environmental impact generated by this production affects the sustainability of the process, especially when it is not given a treatment and proper use to the main waste, such as ash, filter cake and bagasse.

On the other hand, in order to mitigate the affectations, work must be done on improving worker protection and hygiene. It is necessary to dispose a wastewaters collection tank to proceed with treatment before its discharge into tributaries or other uses.

Although at the level of factories, the Ecuadorian agroindustry of panela is artisan and rudimentary, there 
are opportunities for improvement by studies to intensify the process, since they allow raising efficiency, quality and care of the environment. Globalization and markets demand quality and harmless products, under the slogan of cleaner production.

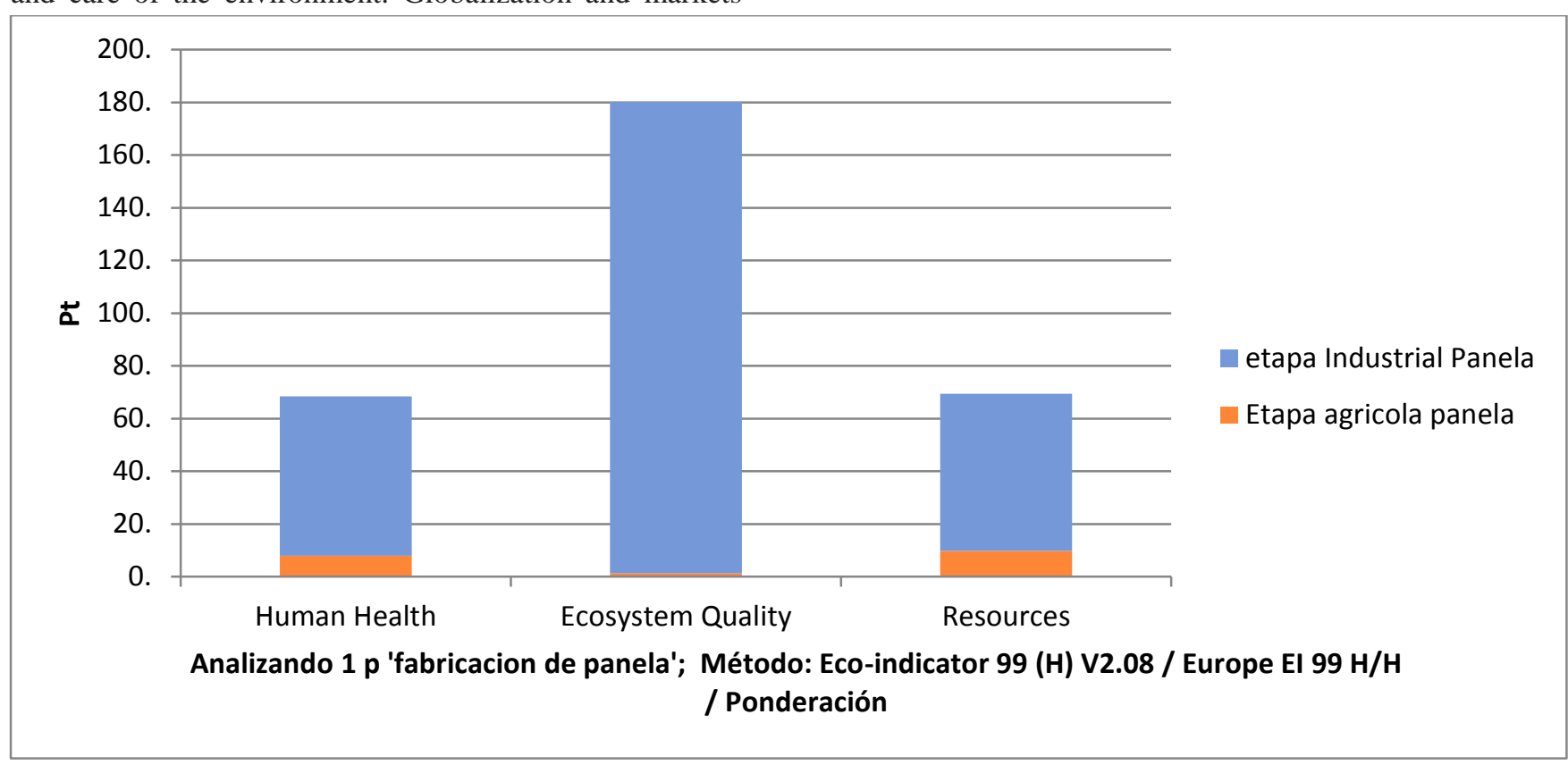

Fig.6: Contribution of the agricultural and industrial stages to the damage categories of the Eco-Indicator 99 expressed in points

\section{CONCLUSIONS}

The Ecuadorian agroindustry of panela, being a more artisan activity than industrial is categorized in group II, it is considered of low impact and requires an environmental record, but because of its productive linking it generates problems that affect the environment despite being a fundamental pillar for rural social, economic, cultural and important development for the sovereignty and food and nutritional security of the country.

The use of bagasse as fuel for the generation of energy in this type of burners to the production of panela is better and less polluting than the use of firewood or tires, so it is necessary to focus on studies of optimization of burners and efficient use of fuels.

The Life Cycle Analysis of the process showed that the greatest impact is originated in the industrial stage with $94 \%$ of contribution and a more representative impact is exhibited on the effects of respiration of inorganic compounds, acidification / eutrophication, climate change and land use.

The contribution to the categories of damage of the EcoIndicator 99 expressed in points is superior for the Quality of the Ecosystem, with respect to Human Resources and Health; therefore, reveals the need to look for executive solutions that ensure its progress, productivity, quality and safety for sustainability.

\section{REFERENCES}

[1] Goedkoop Mark; Effting Suzanne; and Collignon Mercel, 1999. Manual Práctico de ecodiseño. Anexo Eco-indicador 99. Método para evaluar el impacto ambiental a lo largo del ciclo de vida. Holanda, p. 5. Pdf.

[2] Kumar, A. 2010. An Empirical Study on Gur (Jaggery) Industry. Indian Institute of Management Ahmedabad-380 015. India. W.P. http://ssrn.com/abstract=1783403. (Accessed 03 January 2016), p.1-19.

[3] FAO, 2013. Agroindustria para el desarrollo. Food and agricultural organization, Roma. http://www.fao.org/docrep/017/i3125s/i3125s00.pdf. (Accessed 02 January 2016), p. 283.

[4] Quezada, W, 2015. Procedimiento para la intensificación y reconversión de instalaciones paneleras. Tesis presentada en opción al Grado Científico de Doctor en Ciencias Técnicas, Especialidad Ingeniería Química en la Universidad Central Marta Abreu de Las Villas, Cuba.

[5] Quezada Walter; González Erenio; Quezada Walter David and Mera Cristina, 2016. Cane Honey: Process, Quality and Harmlessness. International Journal of Engineering Research. doi: 10.17950. Volume No.5, Issue No.7. 589-593.

[6] Rodríguez Gonzalo, García Hugo, Roa Zulma, Santacoloma Pilar, 2007. Panela production as a 
strategy for diversifying incomes in rural area of Latin America. Roma.

[7] Quezada, W., and Gallardo, I, 2014a. Obtención de extractos de plantas mucilaginosas para la clarificación de jugos de caña. Revista Tecnología Química. RTQ. 34(2):114/123. Cuba.

[8] Quezada, W., and Gallardo, I, 2014b. Clarificación del jugo de caña mediante el empleo de plantas mucilaginosas. Instituto Cubano de Investigaciones de los Derivados de la Caña de Azúcar. ICIDCA. 3:41-48. Cuba.

[9] García María, 2004. Hornillas Paneleras. Evaluación de su Impacto ambiental. Revista Innovación y Cambio Tecnológico, pp. 20-29. Corpoica. Colombia. www.corpoica.org.co - Artículos científicos.

[10] Rodríguez Gonzalo, 2005. La agroindustria rural de la panela en Colombia. Roles, Problemática y Nuevos Retos. Corpoica. Colombia. www.corpoica.org.co - Artículos científicos.

[11]ChidiK Martina y Murmis M., 2003. Gestión ambiental en la agroindustria, competitividad y sustentabilidad, p. 7.

[12] da Silva Carlos, Doyle Baker, Andrew W. Shepherd, Chakib Jenane y Sergio Miranda da Cruz, 2013. Agroindustrias para el desarrollo. FAO. Italia, 2, 254.

[13]Zaror C. 2013. Introducción a la ingeniería ambiental para la industria de procesos. Universidad de Concepción. Chile, pp. 3-7.

[14] Norma Cubana NC ISO 14040. 2009a. Gestión Ambiental-Análisis del Ciclo de Vida-Principios y Marco de Referencia. [ISO 14040:2006 IDT. Habana, Cuba. Oficina Nacional de Normalización.

[15] NC-ISO 14044. 2009b. Gestión Ambiental-Análisis de Ciclo de Vida-Requisitos y Directrices (ISO 14044: 2006, IDT). Oficina Nacional de Normalización. Cuba.

[16] Renee L., 2002. Cornelissen and Gerard G. Hirs. The value of the exergetic life cycle assessment besides the LCA. Energy Conversion and Management 43. Elsevier. Science Ltd. Netherlands. PII: S01968904(02) 00025- 0; Pp.1417-1424.

[17] Contreras Ana; Rosa Elena; Van Langenhove Herman; Santos Herrero Ronaldo; Pérez Gil Maylier; Casas Ledón Yannay; Dewulf Jo. 2013. Exergetic analysis in cane sugar production in combination with Life Cycle Assessment. Journal of Cleaner Production. ELSEVIER. 59 (15)- 43-50.

[18] Contreras Moya Ana; Rosa Domínguez Elena; Pérez Maylier; Van Langenhove Herman, 2009. Comparative life Cycle of four alternatives for using by-products of cane sugar production. Journal of Cleaner Production. ELSEVIER. 17 (8). 772-779.

[19] Aguilar G.; Campos A.; Forcada A.; Sören Bjön Rüd and Martínez Segio, 2013. Estudio de Análisis de Ciclo Vida (ACV) del manej o de envases de bebidas de polietileno tereftalato (PE T) en la fase de pos-consumo Instituto Nacional de Ecología y Cambio Climático, INECC-Cooperación Alemana al Desarrollo. GIZ., p.4. 1-57.

[20]UNEP, (2004). ¿Por qué Adoptar un enfoque de ciclo de vida?. Life Cycle. Una publicación de las Naciones Unidas. ISBN: 92-807-24500-9, p. 6.

[21] Arne Remmen, Allan Astrup Jensen Jeppe Frydendal, and Danish Standards, 2007. Life Cycle Management A Business Guide to Sustainability. UNEP. United Nations Environment Programme, EEUU, p. 12.

[22] Norris Gregory; Suppen Nydia; Paula M. do Nascimento Ana and Lie Ugaya Cássia Maria, 2005. ACV - conceitos para o desenvolvimento industrial na américa latina. Impactos socio-económicos en el análisis de ciclo de vida de productos: de un análisis ambiental de ciclo de vida (ACV) a un ACV sustentable en latino-america. Brasil, p. 40.

[23] Suppen Nydia and van Hoof Bart, 2005. Conceptos básicos del Análisis de Ciclo de Vida y su aplicación en el Ecodiseño. México, pp. 1-40.

[24] Cámara de Industrias y Producción, 2015. Boletín de Ambiente y Seguridad Ambiental. Boletín No 25. Ecuador. Pdf.

[25] Ministerio del ambiente, 2014. Catálogo de categorización nacional ambiental CCAN. Anexo 1. http://www.cip.org.ec/attachments/article/2285/ANE XO\%201\%20CCAN.pdf. [consulta: 11 de agosto 2014].

[26] Ministerio del Ambiente, anexos 1, 2 y 5., 2002. Norma de calidad ambiental del recurso suelo y de descarga de efluentes: recurso agua-libro vi-anexo 1 . Criterios de remediación para suelos contaminadoslibro vi-anexo 2. Límites permisibles de niveles de ruido ambiente para fuentes fijas y fuentes móviles, y para vibraciones-libro vi-anexo 5. Quito Ecuador.

[27] Sánchez O.; Cardona C. and Sánchez D., 2007. Análisis de ciclo de vida y su aplicación a la producción de bioetanol: Una aproximación cualitativa. Revista Universidad EAFIT. Vol. 43. No. 146. Colombia, pp. 59-79. 